\title{
Impact of Individual Feelings of Energy on Creative Work Involvement: A Mediating Role of Leader-Member Exchange
}

\author{
Muhammad Shahnawaz Adil * Kamal bin Ab Hamid ${ }^{\dagger}$
}

\begin{abstract}
Individual feelings of energy (IFE), creative work involvement (CWI) and leadermember exchange (LMX) are understudied areas in Pakistan. The purposes of this study are: a) to analyze the mediating role of LMX on the relationship between IFE and CWI; and b) to evaluate whether the LMX relationship mediates differently for non-managerial staff, supervisors, middle and senior managers. A sample of 300 responses is drawn from the manufacturing companies of Karachi using a questionnaire administered to them. Exploratory factor analysis is used to extract three orthogonal constructs (namely, IFE, CWI, and LMX) and their convergent and discriminant validity are established through confirmatory factor analysis. Both composite and $\operatorname{MaxR}(H)$ statistics are estimated to ensure the reliability of the three constructs. The results show that LMX partially mediates the positive relationship between IFE and CWI. In addition, the results of the multi-group mediation analysis for different levels of responsibility show that LMX partially mediates in case of middle and senior management only. However, it does not mediate for non-managerial staff and supervisors. The most important theoretical contribution of the study in the existing knowledge of leadership-creativity relationship is that LMX partially mediates the relationship between IFE and CWI. Besides, this is one of the first reports in the context of the manufacturing companies of Pakistan.
\end{abstract}

Keywords: Leader-member exchange (LMX); energy, creativity, manufacturing, Pakistan.

\section{Introduction}

In the 21st century, the knowledge-based economy predominantly demands more employees' productivity and creativity (Atwater \& Carmeli, 2009). During the era of hypercompetition, it becomes increasingly difficult and challenging for the competing firms to gain and then sustain their competitive advantage (D'aveni, 1995). Wilson and Gilligan (2005) exemplified that there are three distinctive sources of competitive advantage: a) a superior market position (e.g. a differentiated competitive stance, a lower cost base or a protected niche); b) a superior knowledge and/or relationship base (e.g. detailed customer knowledge, trade relationships, technical expertise, political links, or cartel membership);

\footnotetext{
*Assistant Professor, Department of Management Sciences, IQRA University, Karachi, Pakistan.

Doctoral Candidate, COB-School of Business Management, Universiti Utara Malaysia, Malaysia E-mail:adil.s@iuk.edu.pk

$\dagger$ Associate Professor, COB-School of Business Management, Universiti Utara Malaysia, Malaysia.

Acknowledgement:The authors would like to thank Dr. James Gaskin (Assistant Professor, Department of Information Systems, Brigham Young University, Utah, United States) for uploading his very useful video tutorials of AMOS on his StatWiki Website. The authors would like to thank both reviewers for their valuable suggestions to improve the manuscript.
} 
and c) a superior resource base (e.g. size and economics of scale, financial structures, strategic alliances, the breadth of geographic coverage, marketing and manufacturing flexibility, image/reputation, or channel control). In fact, creativity is now considered as one of the major goals of many high-performance organizations (Mumford, Scott, Gaddis, \& Strange, 2002). Creativity may be defined as "the production of novel and useful ideas by an individual or small group of individuals working together" (Amabile, 1988). In contrast, innovation is referred to as the premeditated application of creative ideas, procedures, and products (West \& Farr, 1990).

\section{Feelings of Energy and Creative Work Involvement}

In contrast with slow working environment with few surprises, the creative work environment is a dynamic working environment with frequent and sudden surprises (Ekvall, 1996). Therefore, leaders should strive to look for better and cost-effective ways through which they could potentially induce competitive level of energy among employees to strengthen creative working environment. Furthermore, individual feelings of energy (IFE) tend to reflect an individual's enthusiasm and vigor to get them engaged in performing a particular assignment (Quinn \& Dutton, 2005) so that they could contribute with their creative ideas on time. However, it is not fairly so easy to remain creative whenever there is a call from the management (Polewsky \& Will, 1996). Unlike conventional office working environment, creative work often needs to get energy from its surroundings therefore, creative people require special working conditions involving entrusting, supportive and comfortable atmosphere so that their creative ideas could be materialized into a reality in near future. In other words, the creative work involvement differs from the day-to-day routine tasks because creativity requires relatively more efforts, feelings of energy, proactive concentration, commitment, and consistency (Atwater \& Carmeli, 2009).

Since demonstrating individual feeling of energy is easy to demonstrate and dynamic, it requires a comfortable working environment so that employees could exert maximum potential of their creative skills at workplace. Moreover, it is generally understood that not every person in an occupational setting is capable enough to think creatively. This postulate is largely affected by inadequate working conditions which are usually coupled with different organizational variables e.g. workload, peer relationships, management support, trust in management, less valuable or non-competitive rewards and compensations plans, timely recognition of efforts, constructive unbiased feedback, etc.

The notion that "feelings are like water" may be easily observed at workplace. One could relate the feeling of energy with the occupational rewards and widespread recognition of efforts. Indeed, employees feel their inherent feature of human emotions throughout their body which motivate them to bring more creative ideas. An imperturbable (or unexcited) employee could possibly meander the creative work environment. The stream of feeling of energy (or vigor) needs continual support from the environment in which one operates. More specifically, while considering the gender differences at workplaces, the relationship between individual feeling of energy and creative work involvement is mainly affected by the quality of reciprocal relationship between the leader and the member (called leader-member exchange or LMX). In other words, a high-quality LMX relationship would 
certainly improve the relationship between individual feeling of energy and creative work involvement.

\section{Leader-Member Exchange (LMX) Theory}

The leader-Member Exchange (LMX) theory finds its roots in the social exchange theory (Blau, 1964; Gouldner, 1960) and relational leadership (Carmeli, Reiter-Palmon, \& Ziv, 2010). The LMX theory (Graen \& Uhl-Bien, 1995) was formerly known as Vertical Dyad Linkage Theory in 1975. This theory argues that the leader classifies subordinates into two distinct groups: high-quality in-group and low-quality out-group. People who are in the high-quality in-group enjoy maximum possible monetary and non-monetary benefits, rewards, trust, recognition, support, etc. whereas out-group employees experience lowquality relationship with the leader involving low level of trust and privileges. Dutton (2003) has argued that a high-quality interpersonal relationship not only energizes the employees' behavior at workplace but also increases their involvement with their duties.

Recently, Friedrich, Griffith, and Mumford (2016) enhanced the collective leadership framework (Friedrich, Vessey, Schuelke, Ruark, \& Mumford, 2009) and evaluated several antecedents of three forms of collective leadership behaviours (i.e. communication, network development, and leader-team exchange). They concluded that a leader may promote collective leadership in teams with a variety of different means however, these ways mainly depend on team and task characteristics as well as the individual behavioural differences of leaders (e.g. emotional intelligence, overall experience, and personality traits).

Furthermore, Little, Gooty, and Williams (2016) tested a model which analyzed how leaders' specific behavioral strategies help them manage the negative emotions of their followers. More specifically, the study established a direct relationship of situation modification, cognitive change, attentional deployment, modulating the emotional response with organizational citizenship behavior (i.e. interpersonal work relationships called OCBIs) and job satisfaction via LMX of 163 matched dyads from a large university in the south eastern United States. They concluded that a number of interpersonal emotion management strategies of a leader not only promote but also strengthen LMX relationship and follower's OCBIs.

Pakistan is a developing country with scant empirical evidences on antecedences and outcome of LMX relationship with minor exceptions. For instance, Naseer, Raja, Syed, Donia, and Darr (2016) analyzed the detrimental effects of despotic leadership (or dictatorship) on employee creativity. They argued that organization could face the serious repercussion of despotic leadership behavior in the situation where employees perceive high organizational politics. Albeit, high-quality LMX relationship leads to desirable organizational outcomes, this relationship may turn out to be detrimental if the follower is engaged with a despotic leader.

In addition, previous authors have studied LMX relationship in relation with different organizational variables e.g., affective commitment (Imran \& Fatima, 2013), organizational citizenship behavior (Imran \& Fatima, 2013; Ishaq, Munazer, Hussain, Asim, \& Cheema, 2012; Nazir, Aslam, \& Nawaz, 2011; Shaukat, Senin, \& Ahmed, 2012), intention to leave (Adil \& Awais, 2016; Imran \& Fatima, 2013), perceived organizational support (Ismail, 
Jafri, \& Khurram, 2011; Shaukat et al., 2012), job satisfaction (Shaukat et al., 2012), distributive justice (Nazir et al., 2011), self-esteem (Ismail et al., 2011), task and contextual performance (Saboor, Mukhtar, \& Sadiq, 2015), and procedural justice (Ishaq et al., 2012).

In the past, authors (e.g. (Jung, Chow, \& Wu, 2003; Tierney \& Farmer, 2004)) have asserted that leadership is an important element to both creativity and innovation but the process through which a leader attempts to engage his subordinates are still an underresearched domain (Amabile, Schatzel, Moneta, \& Kramer, 2004; Atwater \& Carmeli, 2009; Mumford et al., 2002). Besides, a very little evidence is available regarding how and under what circumstances an employee remains creatively involved at work (Carmeli \& Schaubroeck, 2007). Previous studies have used LMX as a predictor to estimate different organizational outcomes however, none of afore-mentioned studies has explored its covariance-based mediating (or indirect effect) on the relationship between individual feeling of energy and creative work involvement. In addition, these three variables have not been studied in the context of Pakistan too. Therefore, this study addresses this theoretical gap by answering the following research questions in the context of the manufacturing companies of Karachi:

- What is the impact of individual feeling of energy on leader-member exchange and creative work involvement?

- Is leader-member exchange positively related with creative work involvement?

- Does LMX relationship mediate the relationship between individual feelings of energy (IFE) and creative work involvement (CWI)?

- Does the LMX relationship mediate differently for the employees having different level of responsibilities (i.e. non-managerial staff, supervisors, middle and senior managers)? It is important to note that these levels refer to the 'designation' a person normally holds in the manufacturing companies of Pakistan.

\section{Theoretical Background and Hypotheses}

\section{Feelings of Energy and LMX}

Pakistan is generally perceived as a country which belongs to a high-power distance culture where people often accept multiple hierarchies with narrow span of control. This power distance sometimes weakens the process of faster rate of information sharing across different levels of organization. Although, young and technologically-savvy generation increasingly believe in reducing this power distance, the traditional operating systems do not allow them to observe the true feeling of energy from the higher management. Considering a longestablished and marginally-inflexible organizational structure, (Kumar \& Raghavendran, 2015) noted that large organizations do not allow their employees to exercise risky (or innovative) decisions on frequent basis. Consequently, employees start to develop a riskaversive attitude for a longer period of time while performing their official responsibilities. 
Both managerial and non-managerial employees serve as integral parts of a creative organization where particularly managers help perpetuate risk-aversive behavior in relatively smaller organizations. It is because of the fact that managers can effectively enhance employee creativity and organizational innovativeness by providing creative people with organizational social support and reasonable degree of psychological empowerment(Çekmecelioglu \& Özbag, 2016). In contrast, Grabner and Speckbacher (2016) argued that a substantial application of formal organizational controls would be required to sufficiently manage work systems when an organization heavily relies on employee creativity. They called this phenomenon as a 'dilemma' because at one side such controls enable management to track employee creative performance however, on the other side it may undermine employee creativity because creative people prefer to work independently without having any major control mechanisms. It not only negatively affects their creative thinking but also render them unable to meet milestones of creative projects on time.

To better understand the individual feeling of energy towards creativity, managers should adopt the practice of thoroughly assessing one's maternal sensitivity (Cantero, Alfonso Benlliure, \& Melero, 2016), dark side of personality (Dahmen Wassenberg, Kammerle, Unterrainer, \& Fink, 2016); meta-cognition and intrinsic motivation (Hong, O'Neil, \& Peng, 2016) and above all, their gender differences in the self-assessment of creative skills (Kemmelmeier \& Walton, 2016).

Individual feelings of energy (IFE) have a direct relationship with LMX. Due to highquality LMX relationship, employees enjoy low power distance with their superiors therefore, they are confident enough in negotiating disparate expectations with their superiors regarding their CWI (Wang \& Cheng, 2010). At one side, the adequate level of job autonomy increases the sense of responsibilities of one's job (Parker \& Sprigg, 1999), and on the other side, in-group LMX relationship further strengthens the CWI of employees which tends to increase when the expectations of the superiors also increase (Bezuijen, van den Berg, van Dam, \& Thierry, 2009; Tierney \& Farmer, 2004).

Previous literature has shown the importance of job autonomy as one of the core job characteristics (Hackman \& Oldham, 1976). With job autonomy, employees could try out different combinations of working practices (Wang \& Cheng, 2010) so that side-by-side their creativity could bring cost-effective results (Adil, 2015). In fact, they tend to look for the most appropriate working practices that best suit their occupational needs and employer's expectations (Shalley \& Gilson, 2004). In this routine, LMX surely serves as a reinforcing tool for employees in developing and trying out their creative (but sometimes risky) ideas. In contrast, employees with low-quality LMX relationship are not inherently encouraged to try out creative ideas at workplaces because they do not have the same management support, trust, and likings than their counterpart (Volmer, Spurk, \& Niessen, 2012).

According to the LMX theory, a dyadic relationship is established which determines a basis of quality of communication and coordination between a leader and follower. Highquality relationship enables the followers to gain various occupational benefits including trust, appreciation, recommendation, promotions, etc. whereas, low-quality relationship often reverts in the form of a negative relationship involving low level of trust and all ethically-possible disliking. Because of the high-quality (in-group) relationship the follower 
feels a sense of energy and more motivation towards performing job duties. A sense of more ownership towards the leader usually brings considerable amount of benefits to both of them (Graen \& Uhl-Bien, 1995). For instance, when a leader gets better job opportunities in other organizations, she tends to pull her reliable subordinates from the previous employer with whom she has established a high-quality (in-group) relationship.

While supporting the notion of IFE, the theory of coordination (Quinn \& Dutton, 2005) maintains that positive and useful communication between people heightens the followers' sense of ownership, proficiency, and adequate level of empowerment at workplace. In short, the theories of coordination and LMX accelerate IFE to achieve assigned goals. This is the "interplay of speech acts and energy" (Quinn, 2007). Since IFE and LMX relationship are closely related with each other the following hypothesis is suggested:

- $H_{1}$ : Individual feeling of energy is positively related to LMX relationship.

\section{LMX and Creative Work Involvement}

The proponents of LMX theory believe that the leader develops a dyadic (two-way) relationship (Graen \& Uhl-Bien, 1995), which is often improved over a period of time due to expectations and completion of role assignments between the two entities. A high quality LMX relationship is characterized by leader's preferences in role assignments, higher and better employee references and recommendations, more privileges and access to necessary information on time. This reflects a reciprocal exchange of relationship between the manager and the sub-ordinate (Blau, 1964; Kelley \& Thibaut, 1978) which normally brings aforementioned set of benefits. Because the leader provides these benefits to the member by virtue of a high-quality relationship, the leader also gains some benefits in return such as high commitment, more job involvement, higher job satisfaction and organizational citizenship. In short, the previous studies show that high-quality LMX relationship is a mutual liking and trust which certainly leads to a number of above-mentioned benefits to leader, member, and ultimately to the organization (Gerstner \& Day, 1997; Ilies, Nahrgang, \& Morgeson, 2007; Liden, Sparrowe, \& Wayne, 1997).

Theoretically, the authors have identified different reasons for a positive relationship between LMX and employee creativity. In contrast with low-quality LMX relationship, it is generally believed that in-group members are more creative thereby they tend to take relatively risky decisions. This is largely attributed to the fact that they receive more recognition, occupational support and commendation from their leader which enable them to perform better than their counterparts (Liden et al., 1997; Tierney, 2008; Tierney, Farmer, \& Graen, 1999). In addition, Scott and Bruce (1994) have asserted that the highquality LMX relationship creates a perception of enabling culture which is necessary for creative work environment (Kark \& Carmeli, 2009). The members who enjoy high-quality LMX relationship tend to reciprocate their highest level of ownership towards the employer (Ilies et al., 2007; Liden et al., 1997).

Empirically, studies have reported a positive relationship between LMX and employee's creativity (e.g., Van Dyne, Jehn, and Cummings (2002)). Similarly, (Atwater \& Carmeli, 2009) have also shown a positive direct effect of LMX on CWI. However, a few studies have 
found no significant relationship between LMX and generation of new ideas (e.g. Clegg, Unsworth, Epitropaki, and Parker (2002)). The relationship between LMX and CWI is further explained by two noticeable meta-analyses (Eder \& Sawyer, 2007; Hammond, Neff, Farr, Schwall, \& Zhao, 2011). Their meta-analyses concluded that a very limited number of primary studies are available on the said relationship and we do not have quite separate findings of CWI or even creativity (Volmer et al., 2012) therefore, there is still a need to further explore the LMX-CWI relationship (Atwater \& Carmeli, 2009).

In addition, leader's change-promoting behavior increases readiness for change among employees (Adil, 2014, 2016). Moreover, the analysis of the direct effect of LMX on CWI is very important in this study (see Figure 1) because of the two main reasons. First, as stated earlier, it would contribute in the existing body of knowledge in understanding the LMX-CWI relationship. Second, managers could also realize that the high-quality LMX relationship certainly increases the CWI which may or may not be affected by job characteristics and design. Hence, the following hypothesis is posited:

- $H_{2}$ : Leader-member exchange relationship will be positively related to creative work involvement.

Figure 1

Conceptual Framework of the Study

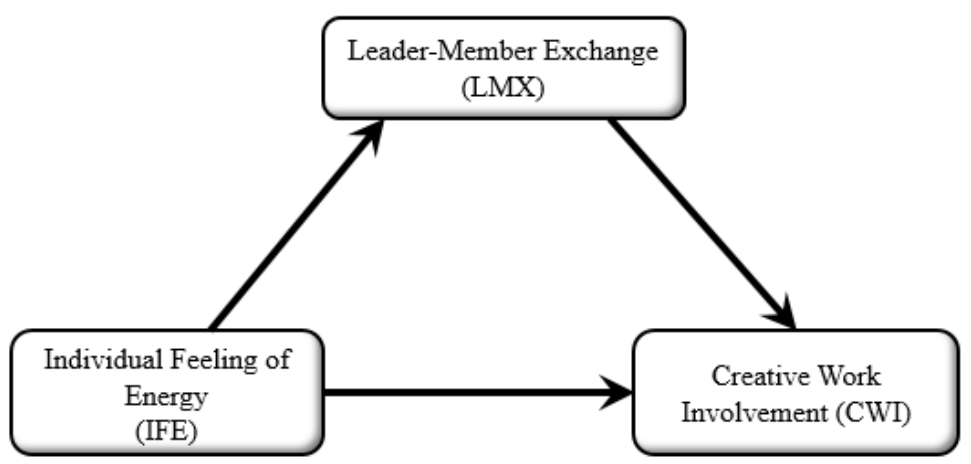

\section{Mediating Role of LMX on the Relationship Between Individual Feeling of Energy and Creative Work Involvement}

The componential theory of creativity (Amabile, 1983) posits that social support from the supervisor not only increases employees' creativity but also enhances their level of motivation and expertise. The high-quality LMX relationship gives values to the efforts of sub-ordinates, shows confidence in their output, and also provides the constructive feedback (Amabile et al., 2004). Previous authors (e.g. (Amabile, 1983)) have concluded that significant amount of time, efforts, and specific working conditions are some of the main prerequisites for creative work behavior. Since both motivation and energy are interlinked 
with each other (Welbourne, Andrews, \& Andrews, 2005) the Broaden-and-Build model (Fredrickson, 1998), the Model of Thriving (Spreitzer, Sutcliffe, Dutton, Sonenshein, \& Grant, 2005), and many other studies (e.g. Isen (1999b, 1999a); Isen, Daubman, and Nowicki (1987)) have also revealed that IFE and exuberance are the main predictors of creative work behavior.

More specifically, the Broaden-and-Build model argues that the positive emotions that employees hold at workplace often tend to enhance their ability of thinking (cognition) and the associated courses of actions which enable them to remain confident enough in generating novel ideas and out-of-the-box thinking (Fredrickson, 2001). Moreover, the Model of Thriving suggests that high-quality interpersonal relationship cultivates specific contextual factors (or enablers) which in turn promote the positive psychological state of mind (Spreitzer et al., 2005). Previously, different authors (e.g. Dutton and Heaphy (2003); Isen et al. (1987); Quinn (2007); Reis and Gable (2003)) have recognized that good interpersonal communication and frequent interactions with colleagues are important sources of IFE which in turn brings liveliness (or 'zest') in their work behavior (Miller \& Stiver, 1997). Creative ideas may produce a number of different cost-effective solutions to a particular problem (Isen, 2004).

While delineating the closed bond between affect and creativity, Professor Amabile of Harvard University and her colleagues have argued that the positive affect enables a person to try out various combinations of alternatives before reaching at a particular cognitive thought (Amabile, Barsade, Mueller, \& Staw, 2005). These variations are largely reinforced by the meaningful interactions with peers and exchange of ideas. This is only possible if the person feels enthusiasm and zeal to intensively use his/her thought process (Kark \& Carmeli, 2009) and get benefits from frequent interactions (Carmeli \& Spreitzer, 2009). In short, it is concluded that positive state of mind and emotions bring IFE to exercise creative work behavior which is mostly due to high-quality LMX relationship.

In essence, high-quality LMX relationship enhances creative work involvement because when a leader increases his expectations regarding the follower's high performance then this Pygmalion effects (Whiteley, Sy, \& Johnson, 2012) not only motivates the follower to further activate her energy to perform better but also enable her to increase her meaningful involvement in creative assignments. The followers should consider leader's expectations as an exclusive opportunity to further accelerate their in-depth understanding and internalization of the organizational creativity needs. A loyal employee generally tends to meet the leader's expectations however, managers should understand that the particular methods they use to assess one's creativity also affect the possible differences in measurement outcomes of creativity (Park, Chun, \& Lee, 2016). Moreover, brain integration and processing speed are significantly associated with creativity dimensions (Travis \& Lagrosen, 2014) which could be possible if there is a high quality LMX relationship between creative people and their superiors. Since it is because of high-quality LMX relationship between superiors and creative people which establishes the impact of individual feelings of energy on creative work involvement, the following hypothesis is tested:

- $H_{3}$ : Leader-member exchange relationship mediates the relationship between individual feelings of energy and creative work involvement. 


\section{Method}

\section{Sample}

The unit of analysis was the employees working in the manufacturing companies of Karachi. These companies are members of Karachi Chamber of Commerce and Industry (KCCI) and were operating in the Sindh Industrial Trading Estates (SITE) Karachi which is spread over 4,700 acres of land area. A total of 450 questionnaires were distributed however, only 300 completely filled forms were received resulting a response rate of 67 percent. Following the guidelines of Tabachnick and Fidell (2007), 34 univariate and multivariate outliers were detected at 99.99 percent CI $(\mathrm{p}<0.001)$ and removed from the dataset leaving a sample of 266 useable responses for inferential data analysis. Table 1 shows the composition of the data.

Table 1

Composition of data $(\mathrm{N}=266)$

\begin{tabular}{clcc}
\hline & & Frequency & Percent \\
\hline \multirow{2}{*}{ Gender } & Male & 177 & 66.5 \\
& Female & 89 & 33.5 \\
\hline Age (in years) & Less than 25 & 53 & 19.9 \\
& 25 to 30 & 93 & 35.0 \\
& 31 to 35 & 52 & 19.5 \\
& 36 to 40 & 30 & 11.3 \\
& 41 to 45 & 29 & 10.9 \\
& 46 to 50 & 07 & 2.60 \\
& above 50 & 02 & 0.80 \\
\hline Marital Status & single & 142 & 53.4 \\
& married & 124 & 46.6 \\
\hline Qualification & Diploma & 21 & 7.90 \\
& Bechelor degree & 79 & 29.7 \\
& Master degree & 138 & 51.9 \\
& Others & 28 & 10.5 \\
\hline Level of responsibility & Non Managerial Staff & 56 & 21.1 \\
& Supervisor & 61 & 22.9 \\
& Middile Management & 120 & 45.1 \\
& Senior Management & 29 & 10.9 \\
\hline Experience & Less than 2 years & 67 & 25.2 \\
& Between 2 to 5 years & 56 & 21.1 \\
& More than 5 years & 143 & 53.8 \\
\hline & & &
\end{tabular}

\section{Measures}

We used a five-point Likert scale ranging from 1 (strongly disagree) to 5 (strongly agree) to measure the following three constructs:

\section{Individual Feelings of Energy (Predictor)}

We adapted seven items of Shirom-Melamed Vigor Measure from Shirom (2003) to measure IFE. A sample item states "I feel I am able to contribute new ideas". Cronbach alpha was 0.87 . 


\section{Leader-Member Exchange (Mediator)}

Six items were adapted from Lee, Scandura, Kim, Joshi, and Lee (2012) to measure LMX relationship. A sample item reads "I can depend on my supervisor at his expense when I really need it". Cronbach's alpha was 0.80 .

\section{Creative Work Involvement (Outcome)}

To measure CWI, seven items were used from Carmeli and Schaubroeck (2007). A sample item includes "I tried out new ideas and approached to problems". Cronbach's alpha was 0.80 .

\section{Analysis and Results}

The data were analyzed by using the 22nd version of SPSS and AMOS. Since this study used only one method of data collection therefore, it was important to analyze common method variance (CMV) bias (Sharma, Yetton, \& Crawford, 2009). Podsakoff, MacKenzie, and Podsakoff (2012) explained that a study without the assessment of common method variance $(\mathrm{CMV})$ bias often report method-biased results. Therefore, likewise previous studies (e.g., (Aulakh \& Gencturk, 2000)) we used Harman's single factor test in SPSS to assess the potential presence of CMV bias. An unrotated one factor solution for all of the 20 items shows that the total variance explained by these items was 33.49 percent. It ensures that CMV bias is not likely to be a significant concern in the study (Podsakoff, MacKenzie, Lee, \& Podsakoff, 2003; Reio, 2010).

\section{Exploratory Factor Analysis (EFA)}

We applied EFA using varimax rotation with Kaiser Normalization method to extract three factors i.e. IFE, LMX, and CWI. As shown in Table 2, out of 20, 18 Likert-scale items were converged onto the required three variables having 0.85 Kaiser-Meyer-Olkin (KMO) measure of sampling adequacy and Bartlett's Test of Sphericity (approx. Chi-Square $=$ 2115.191 , degree of freedom $=153, \mathrm{p}<0.001$ ). The KMO value more than 0.70 shows that the sample is adequate enough to run factor analysis and the significant value of the Bartlett's Test denotes that the correlational matrix is not an identity matrix (Leech, Barrett, \& Morgan, 2005; Tabachnick \& Fidell, 2007; Raza \& Hanif, 2013; Schuster, Bahar Ali Kazmi, Arif, Aslam, \& Ali, 2016; Ali, Raza, \& Chin-Hong, 2015).

Table 2

Correlational Analysis

\begin{tabular}{llclll}
\hline & Mean & Std. Deviation & $\mathbf{1}$ & $\mathbf{2}$ & $\mathbf{3}$ \\
\hline Leader-Member Exchange (LMX) & 4.01 & 0.51 & 1 & & \\
Individual Feeling of Energy (IFE) & 4.16 & 0.52 & $.491^{* *}$ & 1 & \\
Creative Work Involvement (CWI) & 4.12 & 0.47 & $.368^{* *}$ & $.462^{* *}$ & 1 \\
\hline **. Correlation is significant at the 0.01 level (2-tailed). & & &
\end{tabular}


The final EFA solution established both convergent and construct validity hence, all of the items were heavily converged onto their respective factor with higher factor loadings (the minimum was 0.502 ) with higher communalities ranges between 0.31 and 0.82 . The Eigenvalue of each factor is more than 1.0 endorsing that each factor is qualified enough to form a separate factor (Leech et al., 2005; Arif, Afshan, \& Sharif, 2016; Ali \& Raza, 2015). Besides, these three factors cumulatively accounted for 55.87 percent of the total variance (see Table 3). Moreover, the final factor solution also established discriminant validity because there were no cross-loadings in the final rotated solution (Tharenou, Donohue, \& Cooper, 2007) as well as the Pearson correlation (Table 2) between the constructs are less than 0.70 (Hair, Black, \& Babin, 2010; Hair, Sarstedt, Ringle, \& Mena, 2012).

Table 3

Exploratory Factor Analysis $(\mathrm{n}=266)$

\begin{tabular}{|c|c|c|c|}
\hline & $\begin{array}{c}\text { Individual Feeling } \\
\text { of Energy } \\
\text { (IFE) }\end{array}$ & $\begin{array}{c}\text { Creative Work } \\
\text { Involvement } \\
(\text { CWI })\end{array}$ & $\begin{array}{c}\text { Leader-Member } \\
\text { Exchange } \\
(\text { LMX) }\end{array}$ \\
\hline Cronbach alpha & 0.870 & 0.800 & 0.800 \\
\hline Eigenvalue & 3.499 & 3.378 & 3.180 \\
\hline$\%$ of Variance & 19.44 & 18.76 & 17.67 \\
\hline Cumulative \% & 19.44 & 38.20 & 55.87 \\
\hline IFE_3 & .869 & & \\
\hline IFE_2 & .869 & & \\
\hline IFE_1 & .826 & & \\
\hline IFE_7 & .638 & & \\
\hline IFE_4 & .547 & & \\
\hline CWI_4 & & .750 & \\
\hline CWI_5 & & .733 & \\
\hline CWI_3 & & .718 & \\
\hline CWI_2 & & .696 & \\
\hline CWI_6 & & .637 & \\
\hline CWI_1 & & .522 & \\
\hline CWI_7 & & .502 & \\
\hline LMX_2 & & & .785 \\
\hline LMX_5 & & & .719 \\
\hline LMX_4 & & & .696 \\
\hline LMX_1 & & & .670 \\
\hline LMX_6 & & & .606 \\
\hline LMX_3 & & & .554 \\
\hline
\end{tabular}

\section{Confirmatory Factor Analysis (CFA)}

We performed CFA using AMOS in order to test the covariance structure of latent variables. It produced a measurement model which comprised of 11 indicators (Figure 2). In addition to assess convergent validity using average variance extracted (AVE), the composite reliability $(\mathrm{CR})$ of each latent variable was also estimated because it is a more suitable indicator of reliability than Cronbach coefficient alpha (Lin \& Lee, 2005; Molina, LlorénsMontes, \& Ruiz-Moreno, 2007; Raza, Qazi, \& Umer, 2016). Moreover, MaxR(H) which refers to McDonald Construct Reliability is also estimated. Hancock and Mueller (2001) exemplified, "Coefficient $\mathrm{H}$ describes the relation between the latent construct and its mea- 
sured indicators... coefficient $\mathrm{H}$ is unaffected by the sign of indicators' loadings, drawing information from all indicators in a manner commensurate with their ability to reflect the construct" (p. 213). Table 4 shows that the composite reliability (CR) of all of the three latent constructs is greater than 0.70 and average variance extracted (AVE) exceeded 0.50 showing a very good construct reliability and convergent validity respectively (Byrne, 2010). Besides, the square root of the AVE which is shown on diagonals in bold faces is greater than rest of the inter-construct correlations (see Table 4). Hence, the discriminant validity between the three latent constructs is also established (Fornell \& Larcker, 1981). Table 5 shows the model-fit indices with sources.

Figure 2

Confirmatory Factor Analysis (measurement model)

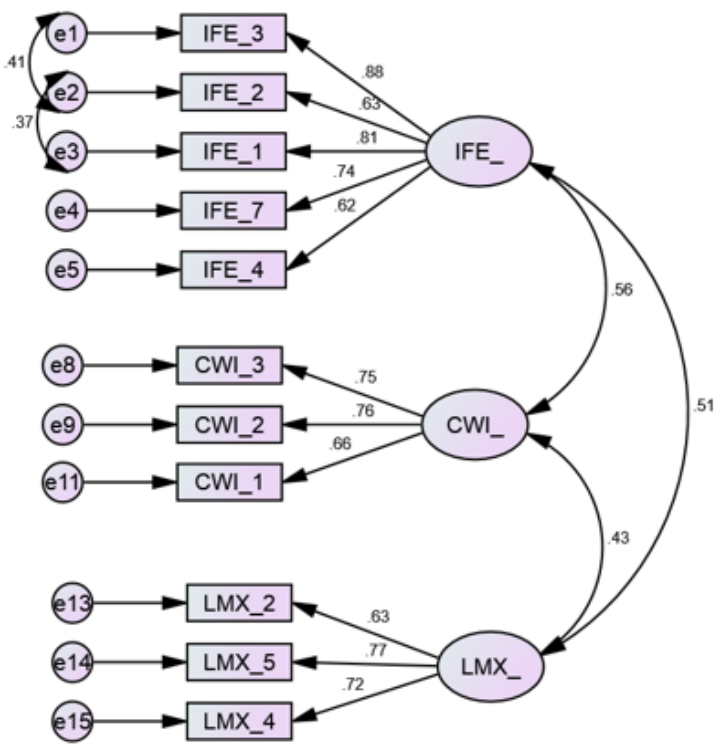

Table 4

CFA Model - reliability and validity

\begin{tabular}{llllcccc}
\hline & CR & AVE & MSV & MaxR(H) & $\mathbf{1}$ & $\mathbf{2}$ & $\mathbf{3}$ \\
\hline Creative Work Involvement & 0.768 & 0.525 & 0.314 & 0.774 & $\mathbf{0 . 7 2 5}$ & & \\
Individual Feeling of Energy & 0.858 & 0.552 & 0.314 & 0.918 & 0.560 & $\mathbf{0 . 7 4 3}$ & \\
Leader-Member Exchange & 0.751 & 0.503 & 0.260 & 0.935 & 0.430 & 0.510 & $\mathbf{0 . 7 0 9}$
\end{tabular}

Notes: $\mathrm{CR}=$ Composite Reliability; AVE $=$ Average Variance Extracted; MSV $=$ Maximum

Shared Variance; $\operatorname{MaxR}(\mathrm{H})=$ McDonald Construct Reliability. AVE $=\left(\sum\right.$ squared standardized loading $) /\left(\sum\right.$ squared. $\mathrm{CR}=\left(\sum\right.$ standardized loading $)$ standardized loading $\left.+\sum \mathrm{IME}\right) 2 /$

( $\sum$ standardized loading $) 2+\sum$ IME) where, IME (indicator measurement error) $=1$ - standardized loading. The square root of AVE is shown on diagonal in bold faces. 


\section{Hypothesis Testing using Mediation Analysis}

To test the hypothesis whether LMX mediates the positive relationship between IFE and CWI, direct and indirect (mediating) effects were estimated in AMOS. Table 6 shows that the direct effect between IFE and LMX (path A) and LMX and CWI (path B) are significantly different from zero $(0.52, \mathrm{p}=0.000 ; 0.15, \mathrm{p}=0.015$ respectively) therefore, mediation analysis can be performed (Baron \& Kenny, 1986). The statistical significance of the path coefficients were tested using the bootstrapping method with bias-corrected confidence estimates (MacKinnon, Fairchild, \& Fritz, 2007; Preacher \& Hayes, 2004). In addition, the 95 percent confidence interval of the indirect (mediating) effects was obtained by using the recommended 5,000 bootstrap samples (Hair, Ringle, \& Sarstedt, 2011; Preacher \& Hayes, 2008). The results of the mediation analysis confirmed that the LMX partially mediates the positive relationship between IFE and CWI hence the hypothesis 1 was supported. The terminology of 'Partial Mediation' (Baron \& Kenny, 1986) is analogous to 'Complementary Mediation' (Zhao, Lynch, \& Chen, 2010).

Table 5

CFA Model: Model-fit indices

\begin{tabular}{lllcc}
\hline Model-Fit Indices & Indicators & Source & Threshold Value & CFA Model \\
\hline Discrepancy Measures: & & & & \\
\hline Minimum Discrepancy & CMIN/DF & Byrne (2010) & $<3.00$ & 2.01 \\
Standardized Root Mean Square Residual & SRMR & Hair et al. (2010) & $\leq 0.08$ & 0.05 \\
Root Mean Square Error of Approximation & RMSEA & Hair et al. (2010) & $\leq 0.08$ & 0.06 \\
\hline Goodness-of-Fit Measures: & & & & \\
\hline Goodness-of-Fit Index & GFI & Jöreskog and Sörbom (1984) & $\geq 0.90$ & 0.95 \\
Adjusted Goodness-of-Fit Index & AGFI & Bagozzi and Yi (1988) & $\geq 0.90$ & 0.91 \\
Normed Fit Index & NFI & Bentler and Bonett (1980) & $\geq 0.90$ & 0.94 \\
Tucker-Lewis Index & TLI & Bentler and Bonett (1980) & $\geq 0.90$ & 0.95 \\
Comparative Fit Index & CFI & Hair et al. (2010) & $\geq 0.95$ & 0.97 \\
\hline
\end{tabular}

\section{Multi-Group Covariance-based Mediation Analysis}

In addition, to meet the second objective of the study, multi-group mediation analysis was performed in AMOS. Each of the respondents was asked to mention the level of responsibly they held. Table 1 and 6 show that within 266 useable responses, there was 56 non-managerial staff (21.1 percent), 61 supervisors (22.9 percent), 120 respondents served at middle management (45.1 percent) and 29 respondents were senior managers (10.9 percent). Likewise the previous hypothesis testing, the direct and indirect (mediating) effects were estimated separately for each of the four groups of employees using 5,000 bootstrap samples at 95 percent confidence intervals. Table 6 particularly shows the type of mediation according to (Baron \& Kenny, 1986) and (Zhao et al., 2010). Notably, 56 non-managerial staff both path $\mathrm{B}$ and path $\mathrm{C}$ ' are not statistically significant from zero $(-0.02, \mathrm{p}=0.942$; $-0.01, \mathrm{p}=0.912$ respectively) therefore, LMX does not mediate between IFE and CWI in case of non-managerial staff. This is in fact 'direct-only (non-mediation)'. Furthermore, in addition to path $\mathrm{B}$ and path $\mathrm{C}^{\prime}$, path $\mathrm{C}$ is not statistically significant from zero $(0.27$, $\mathrm{p}=0.05)$ in case of 61 supervisors. Therefore, because of insignificance of path $\mathrm{C}$, this is 


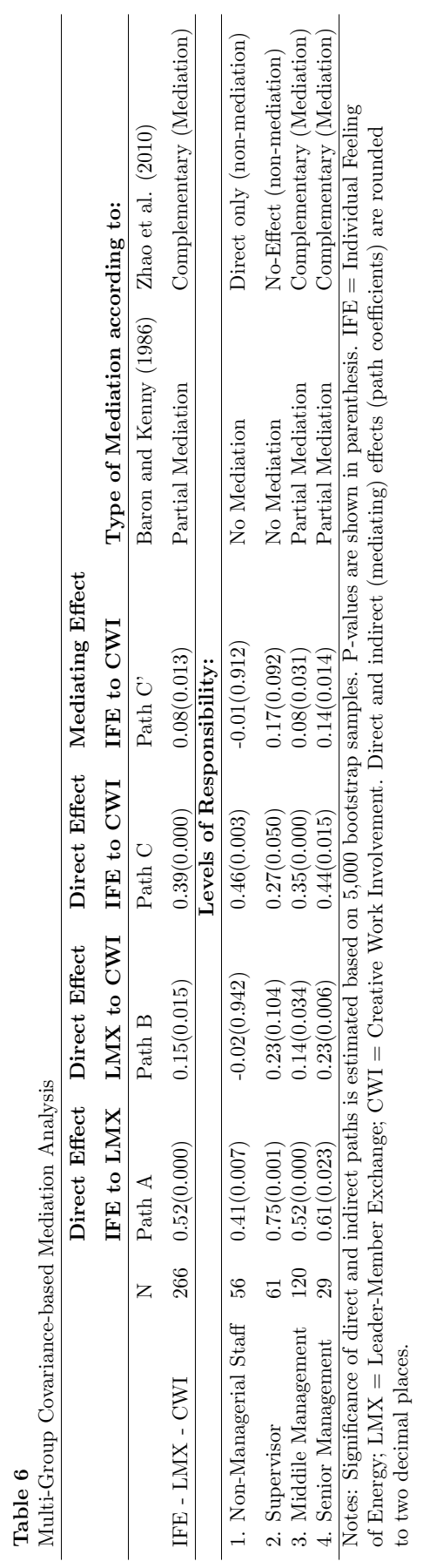


no-effect (non-mediation). In short, LMX does not mediate between IFE and CWI in case of supervisors also.

In contrast, Table 6 also shows that both direct and indirect (mediating) effects are significantly different from zero in case of 120 middle managers and 29 senior managers therefore, it is concluded that LMX partially mediates between IFE and CWI in case of middle and senior managers in the manufacturing companies of Karachi. This is in fact a complementary mediation because both paths were significant however, the standardized coefficients of direct effect (path $\mathrm{C}$ ) were reduced in the indirect (mediating) effect path C'.

\section{Discussion and Managerial Implications}

The objectives of the study are twofold. First, we observed that LMX partially mediated the relationship between IFE and CWI. Second, we further evaluated that LMX did not mediate in the positive relationship between IFE and CWI in case of non-managerial staff and supervisors. However, LMX partially mediated in case of middle and senior managers in the manufacturing companies of Karachi - the largest business and commercial business hub of Pakistan. The analogous terminologies of the type of mediation are also mentioned in Table 6.

Due to today's hyper-competition particularly in the manufacturing industries, it increasingly becomes essential for manufacturing performance to have such employees who are self-motivated to bring creative ideas. Now this is at the management discretion to choose the most cost-effective solution. Acknowledging the intricacies of the impact of LMX on CWI, it is also very important to empower the employees within certain limits so that the notion of job autonomy in association with high-quality LMX relationship could possibly accelerate the organizational learning and employee creativity. Therefore, the management of the manufacturing companies in Karachi should develop a high-quality LMX relationship with subordinates if they intend to increase the creative work involvement among employees. This goal may be achieved through different ways but firstly, it is very important to believe that like any other societal relationships such as husband-wife, parents-children, etc. the dyadic relationship between the leader and the follower is not free from bad times (Hobman, Restubog, Bordia, \& Tang, 2009).

It is argued that individuals should feel energy to cultivate creative work environment so that better and improved ideas could be highlighted and implemented in the manufacturing organizations. This is particularly very important in the manufacturing environment where there is a large influx of state-of-the-art machines and technologies. Recently, Adil (2015) has emphasized that the human resource management practices should be aligned with the corporate strategy in order to observe their direct but positive impact in improving manufacturing performance. Moreover, Heffernan, Harney, Cafferkey, and Dundon (2016) argued that the creativity climate optimizes high-performance work systems which increase organizational performance. The direct relationship between the individual feelings of energy and creative work involvement is essential and high-quality LMX relationship fosters in producing better creative ideas for improving manufacturing performance in Karachi. 
This is only achieved if the power distance between manager and subordinate is reduced in order to observe better bilateral communication and coordination.

In our study, LMX did not mediate the relationship between IFE and CWI in case of non-managerial staff and supervisors. This may be attributed to the fact that nonmanagerial staff is usually responsible for merely performing operational duties in their respective manufacturing units. They are largely semi-skilled employees who are made responsible to achieve daily routine tasks. Although, they may identify some better ways to improve the work efficiencies but perhaps their workload and routine schedule do not allow them to take a bold step to communicate their creative ideas with the top management. Besides, this phenomenon is very devastating in the context of Pakistan where there is a high power distance and uncertainty avoidance. Because of this high power distance, majority of the lower or operational staff always reside in the low-quality (out-group) or sometimes 'unknown zone' in the eyes of the top management. Thus, this workplace attitude does not encourage the non-managerial staff and supervisors to take risky decisions as their actions might not be appreciated or even listened by the top management. In addition to very low literacy rate in the workers class of the manufacturing companies followed by a rapidly-increasing rate of unemployment in Karachi, lower staff is compelled to show their continuance commitment with the employer. Therefore, they could not afford to take risky decisions. Consequently, LMX relationship does not mediate in case of non-managerial staff and supervisors.

On the contrary, middle and senior managers normally work in direct coordination with the leadership thus, they are made responsible to identify creative ideas for improving manufacturing performance. Leadership is an influencing factor for creativity and innovation in organizations (Mumford \& Hunter, 2005) because of the following main reasons: a) leaders sometimes inherently influence their sub-ordinates through their charismatic personality attributes; they are taken as role model (Jaussi \& Dionne, 2003) in the industry; b) leaders provide human, financial and marketing resources and relationship resources (Reiter-Palmon \& Illies, 2004; Tierney et al., 1999) to the followers which certainly help them cultivate creative work behavior; c) leader's invigorative and energizing behavior often lead to motivate managerial staff for generating creative ideas (Atwater \& Carmeli, 2009); and d) leaders can also influence creativity by streamlining the work teams in accordance with the strategic goals (Arad, Hanson, \& Schneider, 1997).

\section{Limitations and Directions for Future Studies}

The findings of this study should be viewed in the light of the following limitations. We used a cross-sectional research design therefore, cause-and-effect relationship may not be determined. Besides, we took the manufacturing companies without regard to specific sectors therefore the findings may not be generalized on the entire manufacturing industry in Karachi. Moreover, gender differences were not considered in this study therefore, future studies may investigate a group-wise mediation analysis in varied contexts. Besides, sample was drawn from Karachi which is one of the very big cosmopolitan cities of the world; its population is generally composed of various cultural background and ethnic beliefs. This 
study did not account for these cultural differences therefore, future studies may ascertain the mediating effect of LMX relationship in varied cultural contexts and dimensions such as masculine versus feminine, uncertainty avoidance, long-term versus short-term orientation, individualism versus collectivism, etc. Since the process through which leaders could engage their employees in creativity is an under-researched domain (Atwater \& Carmeli, 2009), future studies may study creative process engagement (Zhang \& Bartol, 2010) which describes how different ideas are evolved. Besides, occupational engagement in innovative behaviors (Vinarski-Peretz, Binyamin, \& Carmeli, 2011) combines emotions and behavior which might correlate with creative work performance.

\section{Conclusion}

The dyadic relationship between manager and employee plays a significant role in shaping the organizational culture where employees not only feel energy in sharing their creative ideas but also contribute their role in enriching organizational learning for all of its recipients. We found that LMX partially mediated the relationship between individual feelings of energy and creative work involvement. Moreover, it was also revealed during multi-group covariance-based mediation analysis that LMX did not mediate in case of non-managerial staff and supervisors however, it partially (or complementary) mediated for middle and senior managers. This study is perhaps among the first to report the relationship between LMX, individual feelings of energy and creative work involvement in Pakistan. 


\section{References}

Adil, M. S. (2014). Impact of leader's change-promoting behavior on readiness for change: A mediating role of organizational culture. Journal of Management Sciences, 1(2), $102-123$.

Adil, M. S. (2015). Strategic human resource management practices and competitive priorities of the manufacturing performance in Karachi. Global Journal of Flexible Systems Management, 16(1), 37-61.

Adil, M. S. (2016). Impact of change readiness on commitment to technological change, focal, and discretionary behaviors: Evidence from the manufacturing sector of karachi. Journal of Organizational Change Management, 29(2), 222-241.

Adil, M. S., \& Awais, A. (2016). Effect of leader-member exchange, interpersonal relationship, individual feeling of energy and creative work involvement towards turnover intention: A path analysis using structural equation modeling. Asian Academy of Management Journal, 21(2), 99-133.

Ali, M., \& Raza, S. A. (2015). Service quality perception and customer satisfaction in islamic banks of Pakistan: The modified SERVQUAL model. Total Quality Management \& Business Excellence, 1-19. doi: 10.1080/14783363.2015.1100517

Ali, M., Raza, S. A., \& Chin-Hong, P. (2015). Islamic home financing in Pakistan: A SEM based approach using modified TPB model. doi: $10.1080 / 02673037.2017 .1302079$

Amabile, T. M. (1983). The social psychology of creativity. Springer Nature, New York.

Amabile, T. M. (1988). A model of creativity and innovation in organizations. In B. M. Staw, and L. L. Cummings (Eds.), Research in organizational behavior (Vol. 10). JAI Press, Greenwich.

Amabile, T. M., Barsade, S. G., Mueller, J. S., \& Staw, B. M. (2005). Affect and creativity at work. Administrative Science Quarterly, 50(3), 367-403.

Amabile, T. M., Schatzel, E. A., Moneta, G. B., \& Kramer, S. J. (2004). Leader behaviors and the work environment for creativity: Perceived leader support. The Leadership Quarterly, 15(1), 5-32.

Arad, S., Hanson, M. A., \& Schneider, R. J. (1997). A framework for the study of relationships between organizational characteristics and organizational innovation. The Journal of Creative Behavior, 31(1), 42-58.

Arif, I., Afshan, S., \& Sharif, A. (2016). Resistance to adopt mobile banking in a developing country: Evidence from modified TAM model. Journal of Finance and Economics Research, 1(1), 23-38.

Atwater, L., \& Carmeli, A. (2009). Leader-member exchange, feelings of energy, and involvement in creative work. The Leadership Quarterly, 20(3), 264-275.

Aulakh, P. S., \& Gencturk, E. F. (2000). International principal-agent relationships: Control, governance and performance. Industrial Marketing Management, 29(6), $521-538$.

Bagozzi, R. P., \& Yi, Y. (1988). On the evaluation of structural equation models. Journal of the Academy of Marketing Science, 16(1), 74-94.

Baron, R. M., \& Kenny, D. A. (1986). The moderator-mediator variable distinction in 
social psychological research: Conceptual, strategic, and statistical considerations. Journal of Personality and Social Psychology, 51(6), 1173-1182.

Bentler, P. M., \& Bonett, D. G. (1980). Significance tests and goodness of fit in the analysis of covariance structures. Psychological Bulletin, 88(3), 588-606.

Bezuijen, X. M., van den Berg, P. T., van Dam, K., \& Thierry, H. (2009). Pygmalion and employee learning: The role of leader behaviors. Journal of Management, 35(5), 1248-1267.

Blau, P. M. (1964). Exchange and power in social life. Transaction Publishers, USA.

Byrne, B. (2010). Multivariate applications series. structural equation modeling with AMOS: Basic concepts, applications, and programming. Taylor \& Francis Group, New York.

Cantero, M.-J., Alfonso Benlliure, V., \& Melero, R. (2016). Creativity in middle childhood: Influence of perceived maternal sensitivity, self-esteem, and shyness. Creativity Research Journal, 28(1), 105-113.

Carmeli, A., Reiter-Palmon, R., \& Ziv, E. (2010). Inclusive leadership and employee involvement in creative tasks in the workplace: The mediating role of psychological safety. Creativity Research Journal, 22(3), 250-260.

Carmeli, A., \& Schaubroeck, J. (2007). The influence of leaders' and other referents' normative expectations on individual involvement in creative work. The Leadership Quarterly, 18(1), 35-48.

Carmeli, A., \& Spreitzer, G. M. (2009). Trust, connectivity, and thriving: Implications for innovative behaviors at work. The Journal of Creative Behavior, 43(3), 169-191.

Çekmecelioglu, H. G., \& Özbag, G. K. (2016). Psychological empowerment and support for innovation in turkish manufacturing industry: Relations with individual creativity and firm innovativeness. Journal for East European Management Studies, 21(1), $1-10$.

Clegg, C., Unsworth, K., Epitropaki, O., \& Parker, G. (2002). Implicating trust in the innovation process. Journal of Occupational and Organizational Psychology, 75(4), 409-422.

Dahmen Wassenberg, P., Kammerle, M., Unterrainer, H. F., \& Fink, A. (2016). The relation between different facets of creativity and the dark side of personality. Creativity Research Journal, 28(1), 60-66.

D'aveni, R. A. (1995). Coping with hypercompetition: Utilizing the new 7s's framework. The Academy of Management Executive, 9(3), 45-57.

Dutton, J. E. (2003). Energize your workplace: How to create and sustain high-quality connections at work. John Wiley \& Sons, USA.

Dutton, J. E., \& Heaphy, E. D. (2003). The power of high-quality connections at work, in Cameron, K.S. Dutton, J. E., \& Quinn, R. E. (Ed.), Positive Organizational Scholarship. Berrett-Koehler Publishers, San Francisco.

Eder, P., \& Sawyer, J. E. (2007). A meta-analytic examination of employee creativity, Paper presented at 22nd Annual Conference, Society of Industrial and Organizational Psychology, New York.

Ekvall, G. (1996). Organizational climate for creativity and innovation. European Journal of Work and Organizational Psychology, 5(1), 105-123. 
Fornell, C., \& Larcker, D. F. (1981). Evaluating structural equation models with unobservable variables and measurement error. Journal of Marketing Research, 18(1), $39-50$.

Fredrickson, B. L. (1998). What good are positive emotions? Review of General Psychology, 2(3), 300-319.

Fredrickson, B. L. (2001). The role of positive emotions in positive psychology: The broaden-and-build theory of positive emotions. American Psychologist, 56(3), 218 226.

Friedrich, T. L., Griffith, J. A., \& Mumford, M. D. (2016). Collective leadership behaviors: Evaluating the leader, team network, and problem situation characteristics that influence their use. The Leadership Quarterly, 27(2), 312-333.

Friedrich, T. L., Vessey, W. B., Schuelke, M. J., Ruark, G. A., \& Mumford, M. D. (2009). A framework for understanding collective leadership: The selective utilization of leader and team expertise within networks. The Leadership Quarterly, 20(6), 933-958.

Gerstner, C. R., \& Day, D. V. (1997). Meta-analytic review of leader-member exchange theory: Correlates and construct issues. American Psychological Association.

Gouldner, A. W. (1960). The norm of reciprocity: A preliminary statement. American Sociological Review, 25(2), 161-178.

Grabner, I., \& Speckbacher, G. (2016). The cost of creativity: A control perspective. Accounting, Organizations and Society, 48(1), 31-42.

Graen, G. B., \& Uhl-Bien, M. (1995). Relationship-based approach to leadership: Development of leader-member exchange (LMX) theory of leadership over 25 years: Applying a multi-level multi-domain perspective. The Leadership Quarterly, 6(2), 219-247.

Hackman, J. R., \& Oldham, G. R. (1976). Motivation through the design of work: Test of a theory. Organizational Behavior and Human Performance, 16(2), 250-279.

Hair, J. F., Black, W. C., \& Babin, B. J. (2010). Multivariate data analysis. Pearson Prentice Hall, New Jersey.

Hair, J. F., Ringle, C. M., \& Sarstedt, M. (2011). PLS-SEM: Indeed a silver bullet. Journal of Marketing Theory and Practice, 19(2), 139-152.

Hair, J. F., Sarstedt, M., Ringle, C. M., \& Mena, J. A. (2012). An assessment of the use of partial least squares structural equation modeling in marketing research. Journal of the Academy of Marketing Science, 40(3), 414-433.

Hammond, M. M., Neff, N. L., Farr, J. L., Schwall, A. R., \& Zhao, X. (2011). Predictors of individual-level innovation at work: A meta-analysis. Psychology of Aesthetics, Creativity, and the Arts, 5(1), 90-105.

Hancock, G. R., \& Mueller, R. O. (2001). Rethinking construct reliability within latent variable systems. Scientific Software International, Inc., USA.

Heffernan, M., Harney, B., Cafferkey, K., \& Dundon, T. (2016). Exploring the hrmperformance relationship: The role of creativity climate and strategy. Employee Relations, 38(3), 438-462.

Hobman, E. V., Restubog, S. L. D., Bordia, P., \& Tang, R. L. (2009). Abusive supervision in advising relationships: Investigating the role of social support. Applied Psychology, $58(2), 233-256$. 
Hong, E., O’Neil, H. F., \& Peng, Y. (2016). Effects of explicit instructions, metacognition, and motivation on creative performance. Creativity Research Journal, 28(1), 33-45.

Ilies, R., Nahrgang, J. D., \& Morgeson, F. P. (2007). Leader-member exchange and citizenship behaviors: a meta-analysis. Journal of Applied Psychology, 92(1), 269277.

Imran, A., \& Fatima, J. (2013). Subordinates perception of $\operatorname{lmx}$ and performance proxies. Middle-East Journal of Scientific Research, 18(6), 796-802.

Isen, A. M. (1999a). On the relationship between affect and creative problem solving. John Wiley \& Sons, New York.

Isen, A. M. (1999b). Positive affect, handbook of cognition and emotion. John Wiley \& Sons, New York.

Isen, A. M. (2004). Positive affect facilitates thinking and problem solving. Cambridge University Press, United Kingdom.

Isen, A. M., Daubman, K. A., \& Nowicki, G. P. (1987). Positive affect facilitates creative problem solving. Journal of Personality and Social Psychology, 52(6), 1122-1131.

Ishaq, M. I., Munazer, N., Hussain, M. M. N., Asim, A. I., \& Cheema, L. J. (2012). Assessment of $\operatorname{lmx}$ as mediator in procedural justice-organizational citizenship behavior relationship. The New Educational Review, 29(3), 202-211.

Ismail, K., Jafri, S. K. A., \& Khurram, W. (2011). An evaluation of positive organizational behavior in banking sector of Pakistan: Role of organization based self-esteem and organizational supports. Far East Journal of Psychology and Business, 4(1), 1-16.

Jaussi, K. S., \& Dionne, S. D. (2003). Leading for creativity: The role of unconventional leader behavior. The Leadership Quarterly, 14(4), 475-498.

Jöreskog, K. G., \& Sörbom, D. (1984). Lisrel vi user's guide (3rd edition). Scientific Software, Mooresville.

Jung, D. I., Chow, C., \& Wu, A. (2003). The role of transformational leadership in enhancing organizational innovation: Hypotheses and some preliminary findings. The Leadership Quarterly, 14(4), 525-544.

Kark, R., \& Carmeli, A. (2009). Alive and creating: The mediating role of vitality and aliveness in the relationship between psychological safety and creative work involvement. Journal of Organizational Behavior, 30(6), 785-804.

Kelley, H. H., \& Thibaut, J. (1978). The social psychology of groups. Wiley, New York.

Kemmelmeier, M., \& Walton, A. P. (2016). Creativity in men and women: Threat, otherinterest, and self-assessment. Creativity Research Journal, 28(1), 78-88.

Kumar, H., \& Raghavendran, S. (2015). Gamification, the finer art: fostering creativity and employee engagement. Journal of Business Strategy, 36(6), 3-12.

Lee, K., Scandura, T., Kim, Y., Joshi, K., \& Lee, J. (2012). Examining leader-member exchange as a moderator of the relationship between emotional intelligence and creativity of software developers. Engineering Management Research, 1(1), 15-28.

Leech, N. L., Barrett, K. C., \& Morgan, G. A. (2005). Spss for intermediate statistics: Use and interpretation. Psychology Press, New Jersey.

Liden, R. C., Sparrowe, R. T., \& Wayne, S. J. (1997). Leader-member exchange theory: The past and potential for the future. Research in Personnel and Human Resources Management, 15(1), 47-120. 
Lin, H.-F., \& Lee, G.-G. (2005). Impact of organizational learning and knowledge management factors on e-business adoption. Management Decision, 43(2), 171-188.

Little, L. M., Gooty, J., \& Williams, M. (2016). The role of leader emotion management in leader-member exchange and follower outcomes. The Leadership Quarterly, 27(1), 85-97.

MacKinnon, D. P., Fairchild, A. J., \& Fritz, M. S. (2007). Mediation analysis. Annual Review of Psychology, 58(1), 593-614.

Miller, J. B., \& Stiver, I. P. (1997). The healing connection: How women form relationships in therapy and in life. Beacon Press, Boston.

Molina, L. M., Lloréns-Montes, J., \& Ruiz-Moreno, A. (2007). Relationship between quality management practices and knowledge transfer. Journal of Operations Management, $25(3), 682-701$.

Mumford, M. D., \& Hunter, S. T. (2005). Innovation in organizations: A multi-level perspective on creativity. Multi-level Issues in Strategy and Methods, 4(1), 11-73.

Mumford, M. D., Scott, G. M., Gaddis, B., \& Strange, J. M. (2002). Leading creative people: Orchestrating expertise and relationships. The Leadership Quarterly, 13(6), 705-750.

Naseer, S., Raja, U., Syed, F., Donia, M. B., \& Darr, W. (2016). Perils of being close to a bad leader in a bad environment: Exploring the combined effects of despotic leadership, leader member exchange, and perceived organizational politics on behaviors. The Leadership Quarterly, 27(1), 14-33.

Nazir, M. S., Aslam, M. S., \& Nawaz, M. M. (2011). Mediating role of lmx in distributive justice-organizational citizenship behavior relationship: Evidence from Pakistan. European Journal of Social Sciences, 25(3), 59-68.

Park, N. K., Chun, M. Y., \& Lee, J. (2016). Revisiting individual creativity assessment: Triangulation in subjective and objective assessment methods. Creativity Research Journal, 28(1), 1-10.

Parker, S. K., \& Sprigg, C. A. (1999). Minimizing strain and maximizing learning: the role of job demands, job control, and proactive personality. Journal of Applied Psychology, $84(6), 925-939$.

Podsakoff, P. M., MacKenzie, S. B., Lee, J.-Y., \& Podsakoff, N. P. (2003). Common method biases in behavioral research: a critical review of the literature and recommended remedies. Journal of Applied Psychology, 88(5), 879-903.

Podsakoff, P. M., MacKenzie, S. B., \& Podsakoff, N. P. (2012). Sources of method bias in social science research and recommendations on how to control it. Annual Review of Psychology, 63(1), 539-569.

Polewsky, S., \& Will, H. (1996). Creativity workshops: Tools for innovation in organizations? European Journal of Work and Organizational Psychology, 5(1), 43-51.

Preacher, K. J., \& Hayes, A. F. (2004). Spss and sas procedures for estimating indirect effects in simple mediation models. Behavior Research Methods, Instruments, 8 Computers, 36(4), 717-731.

Preacher, K. J., \& Hayes, A. F. (2008). Asymptotic and resampling strategies for assessing and comparing indirect effects in multiple mediator models. Behavior Research Methods, 40(3), 879-891. 
Quinn, R. W. (2007). Energizing others in work connections, in Dutton, J.E. and Ragins, B.R. (Eds.), Exploring Positive Relationships at Work: Building a Theoretical and Research Foundation. Lawrence Erlbaum Associates, New Jersey.

Quinn, R. W., \& Dutton, J. E. (2005). Coordination as energy-in-conversation. Academy of Management Review, 30(1), 36-57.

Raza, S. A., \& Hanif, N. (2013). Factors affecting internet banking adoption among internal and external customers: A case of Pakistan. International Journal of Electronic Finance, 7(1), 82-96.

Raza, S. A., Qazi, W., \& Umer, A. (2016). Facebook is a source of social capital building among university students evidence from a developing country. Journal of Educational Computing Research, 1-28. doi: 10.1177/0735633116667357

Reio, T. G. (2010). The threat of common method variance bias to theory building. Human Resource Development Review, 9(4), 405-411.

Reis, H. T., \& Gable, S. L. (2003). Toward a positive psychology of relationships. American Psychological Association, Washington, DC.

Reiter-Palmon, R., \& Illies, J. J. (2004). Leadership and creativity: Understanding leadership from a creative problem-solving perspective. The Leadership Quarterly, 15(1), $55-77$.

Saboor, A., Mukhtar, M., \& Sadiq, M. K. (2015). Lmx as a predictor of performance behaviour: Empirical evidence from life insurance sector of pakistan. Journal of Human Resource Management, 3(1), 1-5.

Schuster, P. L.-T., Bahar Ali Kazmi, T., Arif, I., Aslam, W., \& Ali, M. (2016). Students' dependence on smartphones and its effect on purchasing behavior. South Asian Journal of Global Business Research, 5(2), 285-302.

Scott, S. G., \& Bruce, R. A. (1994). Determinants of innovative behavior: A path model of individual innovation in the workplace. Academy of Management Journal, 37(3), 580-607.

Shalley, C. E., \& Gilson, L. L. (2004). What leaders need to know: A review of social and contextual factors that can foster or hinder creativity. The Leadership Quarterly, 15(1), 33-53.

Sharma, R., Yetton, P., \& Crawford, J. (2009). Estimating the effect of common method variance: The method-method pair technique with an illustration from TAM research. MIS Quarterly, 33(3), 473-490.

Shaukat, M. Z., Senin, A. A., \& Ahmed, I. (2012). An exchange perspective of job satisfaction: A study of banking sector of Pakistan. Business Management Dynamics, $1(12), 59-65$.

Shirom, A. (2003). Feeling vigorous at work? The construct of vigor and the study of positive affect in organizations. In Emotional and physiological processes and positive intervention strategies. Emerald Group Publishing Limited, Bingley.

Spreitzer, G., Sutcliffe, K., Dutton, J., Sonenshein, S., \& Grant, A. M. (2005). A socially embedded model of thriving at work. Organization Science, 16(5), 537-549.

Tabachnick, B., \& Fidell, L. (2007). Using multivariate statistics. Pearson, New York. Tharenou, P., Donohue, R., \& Cooper, B. (2007). Management research methods. Cambridge University Press, Melbourne. 
Tierney, P. (2008). Leadership and employee creativity. Lawrence Erlbaum Associates, New York.

Tierney, P., \& Farmer, S. M. (2004). The pygmalion process and employee creativity. Journal of Management, 30(3), 413-432.

Tierney, P., Farmer, S. M., \& Graen, G. B. (1999). An examination of leadership and employee creativity: The relevance of traits and relationships. Personnel Psychology, 52(3), 591-620.

Travis, F., \& Lagrosen, Y. (2014). Creativity and brain-functioning in product development engineers: a canonical correlation analysis. Creativity Research Journal, 26 (2), 239243.

Van Dyne, L., Jehn, K. A., \& Cummings, A. (2002). Differential effects of strain on two forms of work performance: Individual employee sales and creativity. Journal of Organizational Behavior, 23(1), 57-74.

Vinarski-Peretz, H., Binyamin, G., \& Carmeli, A. (2011). Subjective relational experiences and employee innovative behaviors in the workplace. Journal of Vocational Behavior, 78(2), 290-304.

Volmer, J., Spurk, D., \& Niessen, C. (2012). Leader-member exchange (LMX), job autonomy, and creative work involvement. The Leadership Quarterly, 23(3), 456-465.

Wang, A.-C., \& Cheng, B.-S. (2010). When does benevolent leadership lead to creativity? The moderating role of creative role identity and job autonomy. Journal of Organizational Behavior, 31(1), 106-121.

Welbourne, T. M., Andrews, S. B., \& Andrews, A. O. (2005). Back to basics: Learning about employee energy and motivation from running on my treadmill. Human Resource Management, 44(1), 55-66.

West, M. A., \& Farr, J. L. (1990). lnnovation and creativity at work: Psychological and organizational strategies. John Wiley \& Sons, New York.

Whiteley, P., Sy, T., \& Johnson, S. K. (2012). Leaders' conceptions of followers: Implications for naturally occurring pygmalion effects. The Leadership Quarterly, 23(5), 822-834.

Wilson, R. M. S., \& Gilligan, C. (2005). Strategic marketing management: Planning, implementation and control. Oxford: Elsevier Butterworth Heinemann.

Zhang, X., \& Bartol, K. M. (2010). The influence of creative process engagement on employee creative performance and overall job performance: A curvilinear assessment. Journal of Applied Psychology, 95(5), 862-873.

Zhao, X., Lynch, J. G., \& Chen, Q. (2010). Reconsidering Baron and Kenny: Myths and truths about mediation analysis. Journal of Consumer Research, 37(2), 197-206. 